\title{
Perspektif masyarakat di Kota Padang terhadap rencana kebijakan redenominasi mata uang rupiah
}

\author{
Marshely Zulhaisa ${ }^{1}$, Syafruddin Karimi², Endrizal Ridwan ${ }^{3}$ \\ ${ }^{1}$ Jurusan Megister Perencanaan Pembangunan, Universitas Andalas, Padang \\ ${ }^{2,3}$ Fakultas Ekonomi, Universitas Andalas, Padang \\ *E-mail korespondensi: marshelyzulhaisa06@gmail.com
}

\begin{abstract}
This study aims to examine the perceptions of the people in the city of Padang on the plan to redenominate the rupiah currency and see how the redenomination's impact the economy. The data used are primary by distributing questionnaires to the community according to sub-districts in Padang City, where the data are grouped based on the highest level of education attained. The data analysis method in this research is qualitative by using descriptive analysis of the frequency and descriptive analysis of cross-tabulations (crosstabulation). From the results of this study, it was found that some people did not agree with the redenomination policy because they did not understand this policy. From the results of the crosstabulation descriptive analysis, it can be seen that there is a relationship between the level of education and the perception of the impact of redenomination on the exchange rate and consumption patterns. Meanwhile, there is no relationship between education level and knowledge of redenomination, opinion on redenomination policy, and perceptions about the impact of redenomination on inflation and savings.
\end{abstract}

Keywords: Community perspective, Redenomination, Sanering, Inflation, Exchange rate

\begin{abstract}
Abstrak
Penelitian ini bertujuan untuk mengkaji persepsi masyarakat di Kota Padang terhadap rencana kebijakan redenominasi mata uang rupiah dan melihat bagaimana dampak dari redenominasi tersebut terhadap perekonomian. Data yang digunakan adalah primer dengan menyebarkan kuesioner kepada masyarakat menurut kecamatan di Kota Padang, dimana data dikelompokkan berdasarkan tingkat pendidikan tertinggi yang ditamatkan. Metode analisis data dalam penelitian ini secara kualitatif dengan menggunakan analisis deskriptif frekuensi dan analisis deskriptif tabulasi silang (crosstabulation). Dari hasil penelitian ini didapatkan bahwa sebagian masyarakat tidak setuju dengan kebijakan redenominasi sebab mereka tidak paham tentang kebijakan ini. Dari hasil analisis deskriptif crosstabulation terlihat bahwa terdapat hubungan antara tingkat pendidikan dengan persepsi mengenai dampak redenominasi terhadap nilai tukar dan pola konsumsi. Sementara itu tidak terdapat hubungan antara tingkat pendidikan dengan pengetahuan tentang redenominasi, pendapat mengenai kebijakan redenominasi serta persepsi tentang dampak redenominasi terhadap inflasi dan tabungan.
\end{abstract}

Kata kunci: Perspektif masyarakat, Redenominasi, Sanering, Inflasi, Nilai tukar

\section{PENDAHULUAN}

Redenominasi adalah penyederhanaan nilai mata uang tanpa mengubah nilai tukar mata uang tersebut (Alhusain, 2012). Selain itu menurut Dogorawa (2007), redenominasi merupakan proses dimana mata uang nominal baru menggantikan mata uang nominal lama dengan dengan nilai yang tetap sama. 
Redenominasi ini sudah banyak dilakukan oleh negara di dunia. Brazil adalah negara pertama yang melakukan redenominasi pada tahun 1923 (Mohdi dan Reza, 2012). Namun dalam pelaksanan redenominasi tersebut ada negara yang dianggap sukses dan ada juga yang gagal, tetapi dari pengalaman lebih banyak negara yang gagal. Negara yang berhasil dalam pelaksanann redenominasi adalah Turki, Romania dan Polandia (Priyono, 2013). Negara - negara tersebut berhasil karena melakukan redenominasi pada saat inflasi rendah dan stabil. Sedangkan negara yang gagal, antara lain Brazil, Rusia, Argentina, Zimbabwe, Israel, Korea Utara dan lain sebagainya. Mereka meredenominasi mata uang nya pada saat inflasi tinggi (Mohdi dan Reza, 2012).

Di Indonesia redenominasi mulai berkembang dan menjadi topik hangat pada tahun 2010 setelah Bank Indonesia (BI) mewacanakan rencana mereka untuk meredenominasi mata uang rupiah sampai tiga nol (Lianto dan Suryaputra, 2012). Redenominasi bukan pertama kali terjadi di Indonesia, karena pada tahun 1950, 1959 dan 1965 atau pada masa orde lama pemerintah Indonesia sudah pernah melakukan pemotongan nilai mata uang yang lebih dikenal dengan sanering. Namun, sanering berbeda dengan redenominasi karena sanering berarti pemotongan nilai nominal mata uang sekaligus mengubah nilai tukarnya, sehingga daya beli masyarakat juga berubah. Selain itu, sanering dilakukan pada saat terjadi inflasi yang tinggi. Sedangkan redenominasi hanyalah penyederhanaan nilai nominal mata uang, dimana nilai tukar dan daya beli masyarakat tidak berubah. Selanjutnya redenominasi juga dilaksanakan pada saat inflasi yang rendah dan stabil.

Alasan Bank Indonesia untuk melaksanakan redenominasi adalah karena pecahan rupiah Rp 100.000 merupakan pecahan tertinggi kedua di dunia setelah Vietnam yang mencetak pecahan sampai 500.000 Dong (Amir, 2011). Alasan lain, karena dengan nilai nominal mata uang yang terlalu besar seolah - olah mencerminkan bahwa dimasa lalu negara pernah mengalami inflasi yang sangat tinggi atau mengalami kondisi fundamental ekonomi yang kurang baik (Kesumajaya, 2011). Menurut Hardiyanto dan Daulay (2013), alasan BI meredenominasi rupiah adalah karena ketidaknyamanan dan ketidakefisien dalam melakukan transaksi dengan pecahan mata uang yang terlalu besar. Juga untuk mempersiapkan kesetaraan ekonomi Indonesia dengan kawasan ASEAN.

Bank Indonesia menilai bahwa saat ini adalah waktu yang tepat untuk melakukan redenominasi rupiah. Hal ini karena perekonomian Indonesia dalam beberapa tahun terakhir telah berada dalam kondisi yang sehat dan stabil, dengan kisaran iflasi antara 4 sampai 7 persen per tahun (BPS, 2015). Selain itu, juga untuk meningkatkan martabat dan kredibilitas bangsa Indonesia baik dimata nasional maupun internasional. Namun, kebijakan ini memerlukan waktu yang lama, persiapan yang matang dan landasan hukum yang tepat. Selanjutnya, diperlukan sosialisasi yang baik kepada publik agar tidak menimbulkan gejolak ekonomi dan politik dalam masyarakat.

Pelaksanaan redenominasi ini akan dilakukan diseluruh wilayah dan Propinsi di Indonesia, tidak terkecuali di Sumatera Barat bahkan sampai ke daerah Kabupaten atau Kota, seperti di Kota Padang. Kota Padang adalah Ibukota Propinsi Sumatera Barat yang memiliki populasi paling besar. Dimana menurut data Badan Pusat Statistik pada tahun 2017, populasi atau jumlah penduduk Kota Padang adalah sebanyak 902.413 jiwa atau 17,37 persen dari total penduduk Propinsi Sumatera Barat dengan luas wilayah sekitar 694,96 km².

Pada tahun 2017, Kota Padang merupakan Kota dengan penyumbang PDRB terbesar di Sumatera Barat yaitu sebesar 35.197.850,27 juta rupiah dengan laju pertumbuhan ekonomi sebesar 6,35 persen. Jika dilihat dari Indeks Pembangunan Manusia (IPM) Kota Padang adalah sebesar 80,36 persen pada tahun 2017 dan paling tinggi di Sumatera Barat. Selanjutnya, Kota Padang juga termasuk kota dengan posisi 
simpanan masyarakat baik rupiah maupun valuta asing di bank umum dan BPR yang paling tinggi yaitu sebesar 17. 976.348 juta pada tahun 2017 (BPS, 2018).

Selain itu, Kota Padang juga merupakan kota dengan persentase paling tinggi menurut tingkat pendidikan tertinggi yang ditamatkan penduduknya di Sumatera Barat. Dari data BPS pada tahun 2017 lebih banyak persentase penduduk berumur 15 tahun keatas yang menamatkan pendidikan tingkat Menengah Keatas, yaitu sebesar 48,15 persen atau hampir 50 persen.

Karena itu jika dilihat dari beberapa kategori tersebut, seperti dari tingkat populasi, PDRB, IPM, posisi simpanan di bank umum dan BPR serta dari tingkat pendidikan tertinggi yang ditamatkan penduduknya, maka Kota Padang merupakan kota terbesar di Sumatera Barat. Secara umum, di Ibukota Propinsi akses informasi, pengetahuan, arus pembayaran, sistem perbankan dan kegiatan perekonomian lebih bagus dan lebih lancar, kota menjadi pusat perdagangan atau pusat perekonomian, dan sebagai pusat pendidikan serta lebih maju daripada Kota atau Kabupaten lainnya.

Redenominasi yang dilakukan akan menimbulkan dampak terhadap masyarakat di Kota Padang. Dimana terdapat pro dan kontra masyarakat terhadap kebijakan tersebut. Menurut Hardiyanto dan Daulay (2013), hal itu disebabkan karena banyaknya masyarakat yang tidak memahami konsep redenominasi, bagaimana masyarakat menggunakan uang baru di masa transisi dan sebagian masyarakat akan mengira bahwa redenominasi itu sama dengan sanering yang menimbulkan ketidakpercayaan masyarakat terhadap uang dan pemerintah.

Dampak lainnya terjadi money illusion atau disebut juga bias psikologis adalah dampak yang muncul karena perubahan nominal mata uang, maka sebagian masyarakat akan menganggap harga barang menjadi lebih murah (Wibowo, 2013). Hal ini menyebabkan konsumsi menjadi tinggi dan harga barang akan meningkat, sehingga terjadi inflasi kembali yang lebih tinggi, uang menjadi tidak berharga dan nilai tukarnya semakin rendah. Maka diperlukan pengkajian lebih lanjut dan persiapan yang baik untuk melaksanakan kebijakan tersebut, karena setiap kebijakan akan berdampak langsung terhadap masyarakat dan perekonomian di suatu daerah termasuk di Kota Padang.

\section{Redenominasi mata uang rupiah}

Secara sederhana, redenominasi adalah pemotongan jumlah angka nol pada mata uang (Bernholz, 1995). Menurut Alhusain (2012), redenominasi merupakan penyederhanaan nilai mata uang tanpa mengubah nilai tukar mata uang tersebut. Lebih lanjut lagi, redenominasi dapat juga disebut dengan penyederhanaan nilai nominal mata uang dengan mengurangi digit (angka nol) tanpa mengurangi nilai riil mata uang tersebut (Pambudi et al, 2014). Redenominasi mata uang diartikan sebagai peraturan publik yang menyederhanakan pemahaman, penggunaan dan manajemen mata uang nasional melalui penulisan yang baru dan dengan skala yang lebih kecil (Suhendra, dan Handayani, 2012). Sedangkan Ioana (2012) berpendapat bahwa redenominasi mata uang merupakan penurunan nilai moneter mata uang dan termasuk bagian dari strategi reformasi perekonomian yang dilakukan oleh suatu negara. Mosley (2005) menyatakan bahwa redenominasi mata uang ialah salah satu sarana untuk mempertegas kedaulatan moneter dan digunakan untuk menutup proses reformasi.

Jadi, redenominasi mata uang adalah penyederhanaan nilai nominal pada pecahan (denominasi) mata uang suatu negara menjadi lebih kecil dengan cara mengurangi jumlah digit angka nol tanpa mengurangi atau memotong nilai riil mata uang tersebut. Misalnya, nilai Rp 10.000 sebelum redenominasi dapat membeli $1 \mathrm{~kg}$ beras, maka setelah redenominasi dengan menghilangkan tiga angka nol menjadi Rp 10 tetap bisa membeli $1 \mathrm{~kg}$ beras. Hal ini disebabkan karena pemotongan nilai nominal tidak hanya berlaku pada mata uang, namun juga untuk harga barang dan jasa, serta pendapatan sehingga tidak akan mengurangi daya beli masyarakat. 
Syarat atau faktor penentu keberhasilan redenominasi yang harus dilakukan dan dimiliki suatu negara agar berhasil dalam melakukan kebijakan redenominasi mata uang, yaitu kondisi perekonomian yang stabil (tingkat inflasi rendah dan pertumbuhan ekonomi tinggi), adanya jaminan akan stabilitas harga barang dan jasa, sosialisasi yang baik kepada masyarakat, dan dinamika politik yang stabil atau bentuk pemerintahan suatu negara (Lianto dan Suryaputra, 2012).

Redenominasi memiliki dampak positif dan dampak negatif. Melalui redenominasi ini, Rupiah akan terlihat memiliki kekuatan karena nilainya akan mendekati dollar AS, frekuensi pencetakan mata uang juga akan berkurang karena dengan redenominasi tiga angka nol, maka pecahan uang rupiah kertas ribuan akan diganti dengan satu rupiah uang logam yang lebih tahan lama. Sehingga pencetakannya akan lebih jarang dan hal ini diperlukan untuk membangun infrastruktur pembayaran non-tunai dimasa depan, sebab semakin besar digit mata uang maka sistem pencatatan akuntansi akan semakin sulit serta untuk megatasi inefisiensi karena banyaknya waktu, biaya transaksi akibat nilai transaksi yang semakin besar dan mengatasi salah hitung karena jumlah nol yang terlalu banyak (Kesumajaya, 2011).

Namun, redenominasi juga memiliki dampak negatif, karena rencana redenominasi rupiah membutuhkan biaya operasional yang sangat besar. Menurut Kesumajaya (2011) Bank Indonesia harus melakukan pencetakan uang kembali untuk mengganti mata uang lama yang akan di redenominasi. Bagi pelaku usaha dan perbankan, redenominasi rupiah juga memiliki tantangan yang besar karena harus berinvestasi lagi untuk mengganti pembukuan, label barang, dan memperbaharui sistem teknologi informasi.

Selain itu, Bank Indonesia dan pemerintah juga harus mewaspadai dampak sosial yang akan terjadi setelah kebijakan ini diterapkan, seperti terjadinya trauma dan ketidakpercayaan masyarakat pada rupiah, karena mereka menganggap redenominasi ini sama dengan kebijakan pemotongan nilai mata uang (sanering) yang terjadi pada masa orde lama yaitu tahun 1950 (Priyono,2013). Sehingga jika kebijakan ini tidak dibarengi dengan sosialisasi yang baik kepada masyarakat, kebijakan ini akan menjadi bumerang bagi Bank Indonesia sendiri karena masyarakat akan memborong dollar AS dan nilai tukar rupiah akan semakin rendah dari sebelumnyayang dapat menyebabkan inflasi meningkat. Dampak negatif lainnya dari redenominasi menurut Wijaya (2014) adalah terjadi peningkatan harga akibat pembulatan harga terhadap barang yang harganya kurang dari satu rupiah, sehingga inflasi akan meningkat.

Redenominasi juga dapat menyebabkan terjadinya money illusion. Money illusion ini muncul karena perubahan nilai barang akibat redenominasi (Wibowo, 2013). Dimana masyarakat menganggap dan mempersepsikan bahwa harga barang menjadi lebih murah setelah dihilangkannya beberapa digit nol pada mata uang sehingga nilai tukarnya tampak lebih besar, padahal sebenarnya sama saja. Hal ini akan berdampak pada perilaku konsumsi yang semakin besar karena konsumen atau masyarakat merasa harga barang menjadi lebih murah. Selain itu, produsen akan cenderung untuk melakukan pembulatan harga ke atas untuk barang - barang yang harganya lebih murah apabila ketersediaan uang koin sen tidak tercukupi oleh pemerintah dan konsumen pun akan membiarkan hal ini terjadi karena mereka menganggap uang tersebut tidak berharga. Sehingga terjadi kenaikan harga dan akan menyebabkan peningkatan inflasi. Apabila terjadi inflasi maka nilai tukar mata uang dalam negara tersebut akan terdepresiasi.

Rencana redenominasi di Indonesia membutuhkan waktu yang lama dan harus melalui beberapa tahapan, seperti pembuatan Undang- Undang tentang redenominasi, tahap sosialisasi dan persiapan, tahap transisi, dimana pada tahap ini digunakan dua mata uang rupiah yaitu mata uang rupiah lama dan mata uang rupiah hasil redenominasi yang disebut mata uang baru. Kemudian tahap penarikan mata uang lama dan keterangan pada mata uang baru hasil redenominasi akan di hapus. Tahap terakhir Bank 
Indonesia harus mencetak uang baru kembali dan masyarakat akan melakukan transaksi ekonomi dengan mata uang baru seluruhnya (Kesumajaya, 2011).

Kebijakan redenominasi di Indonesia tidak terlepas dari kebijakan Bank Indonesia yang bertujuan untuk mencapai dan memelihara kestabilan nilai rupiah. RUU tentang perubahan harga rupiah atau yang lebih dikenal dengan redenominasi rupiah telah diusulkan oleh pemerintah kepada DPR sebagai prioritas polegnas 2013 (Alhusain, 2102).

Sejak Bank Indonesia mewacanakan rencana untuk meredenominasi rupiah pada akhir tahun 2010, maka kebijakan tersebut telah menyebabkan terjadi pro dan kontra di berbagai kalangan masyarakat. Pendapat yang pro menyatakan bahwa redenominasi membuktikan Indonesia dalam kondisi yang lebih baik sehingga telah siap untuk menerima tantangan baru. Sedangkan yang kontra menyatakan bahwa redenominasi hanya dapat menimbulkan lonjakan inflasi yang dapat membebani masyarakat, bahkan jika terus berlanjut hal ini akan membuat nilai tukar kita jauh lebih rendah dari pada sebelumnya.

Oleh karena itu, sebelum dilaksanakan redenominasi rupiah, pemerintah perlu melakukan persiapan yang matang dan sosialisasi kepada seluruh masyarakat Indonesia agar kebijakan ini dapat dipahami secara utuh. Selain itu persiapan infrastruktur juga sangat penting untuk menghindari terjadinya inflasi (Alhusain, 2012).

Priyono (2013) menyatakan bahwa redenominasi tidak sama dengan sanering, karena redenominasi hanyalah penyederhanaan nilai nominal mata uang. Redenominasi tidak akan mengurangi nilai tukar mata uang dan juga tidak akan mengurangi daya beli masyarakat. Sehingga redenominasi tersebut tidak akan merugikan masyarakat dan redenominasi terjadi pada saat kondisi makro ekonomi yang stabil. Sedangkan sanering adalah pemotongan nilai mata uang sekaligus mengurangi daya beli uang terhadap barang dan jasa. Selain itu, sanering juga terjadi pada saat perekonomian suatu negara tidak sehat yaitu pada saat inflasi tinggi dan pertumbuhan ekonomi rendah.

\section{METODE}

Penelitian yang dilakukan ini adalah penelitian yang menggunakan pendekatan deskriptif kualitatif. Dimana dalam penelitian ini peneliti ingin memperoleh gambaran yang bersifat umum dan komprehensif serta mendalam mengenai persepsi masyarakat di Kota Padang terhadap rencana kebijakan redenominasi mata uang rupiah dan melihat dampaknya terhadap aktifitas perekonomian, yaitu terhadap inflasi, nilai tukar, tabungan dan pola konsumsi.

Penelitian ini dilakukan di Kota Padang yang terbagi dalam 11 Kecamatan, yaitu Kecamatan Bungus, Teluk Kabung, Lubuk Kilangan, Lubuk Begalung, Padang Selatan, Padang Timur, Padang Barat, Padang Utara, Nanggalo, Kuranji, Pauh, dan Kecamatan Koto Tangah. Waktu yang diperlukan untuk menyelesaikan penelitian ini adalah sekitar dua minggu.

Populasi dalam penelitian ini adalah seluruh masyarakat yang terbagi kedalam 11 Kecamatan di Kota Padang yang berjumlah sebanyak 902.413 jiwa pada tahun 2017. Dalam menentukan ukuran sampel minimum pada penelitian ini penulis menggunakan rumus Slovin (Umar, 2000), yaitu sebagai berikut :

$$
n=\frac{N}{1+N e^{2}}
$$

Dimana:

$$
\begin{aligned}
& \mathrm{n}=\text { ukuran sampel } \\
& \mathrm{N}=\text { ukuran populasi } \\
& \mathrm{e}=\text { nilai kritis (standar eror) }
\end{aligned}
$$


Dengan menggunakan nilai kritis sebesar $10 \%$ maka jumlah sampel yang didapatkan adalah sebagai berikut :

$$
\begin{aligned}
& \mathrm{n}=\frac{902.413}{1+902.413(1096)^{2}} \\
& \mathrm{n}=\frac{902.413}{1+9.024,13} \quad \mathrm{n}=99,9
\end{aligned}
$$

Jadi berdasarkan rumus diatas, didapatkan jumlah sampel minimum sebanyak 99 responden. Namun, untuk menghindari kemungkinan sampling error, maka dalam penelitian ini penulis menetapkan jumlah sampel sebanyak 100 responden.

Sampel tersebut adalah masyarakat umum yang berumur 20 tahun keatas yang terdapat pada 11 Kecamatan di Kota Padang. Cara penentuan sampel pada tiap kecamatannya adalah dengan melihat data jumlah penduduk menurut Kecamatan tahun 2017 di Kota Padang. Kemudian didapatkan jumlah sampel dari persentase jumlah penduduk. Selanjutnya sampel dikategorikan lagi berdasarkan tingkat pendidikan tertinggi yang ditamatkan atau ijazah terakhir yang dimiliki responden.

\section{Model penelitian}

Metode analisis data dalam penelitian ini secara kualitatif dengan menggunakan teknik analisis statistik deskriptif. Analisis deskriptif yang digunakan pada penelitian ini yaitu analisis deskriptif frekuensi dan dan analisis deskriptif tabulasi silang (crosstabulation).

Dalam penelitian ini analisis frekuensi bertujuan untuk melihat distribusi dari karakteristik responden, yang terdiri dari tingkat umur responden, jenis kelamin responden, alamat responden, tingkat pendidikan responden, status responden dan pekerjaan responden. Kemudian untuk melihat distribusi persepsi responden terhadap rencana kebijakan redenominasi, yang terdiri dari pengetahuan tentang redenominasi, pendapat tentang rencana redenominasi.

Analisis crosstabulation bertujuan untuk mengetahui hubungan antara persepsi masyarakat di Kota Padang terhadap rencana kebijakan redenominasi mata uang rupiah, yang terdiri dari hubungan tingkat pendidikan dengan pengetahuan tentang redenominasi, dan hubungan tingkat pendidikan dengan pendapat mengenai rencana kebijakan redenominasi. Selain itu juga untuk mengetahui persepsi masyarakat di Kota Padang mengenai dampak redenominasi terhadap aktifitas perekonomian, yang terdiri dari hubungan tingkat pendidikan responden dengan dampak redenominasi terhadap inflasi, hubungan tingkat pendidikan responden dengan dampak redenominasi terhadap tabungan, hubungan tingkat pendidikan responden dengan dampak redenominasi terhadap pola konsumsi, dan hubunga tingkat pendidikan responden dengan dampak redenominasi terhadap nilai tukar (kurs).

Dasar pengambilan keputusan pada crosstab dalam metode Chi-Square didasarkan pada probabilitas (signifikansi).

Hipotesis :

$\mathrm{H}_{\mathrm{o}}=$ Bahwa tidak terdapat hubungan antara baris dan kolom.

$\mathrm{H}_{1}=$ Bahwa terdapat hubungan antara baris dan kolom.

Kriteria signifikansi :

Jika angka $\mathrm{Sig}>0,10: \mathrm{H}_{0}$ diterima.

Jika angka $\mathrm{Sig}<0,10: \mathrm{H}_{0}$ ditolak.

Berdasarkan perbandingan Chi-Square hitung dengan Chi-Square tabel, maka diperoleh hasil sebagai berikut :

Jika Chi-Square Hitung <Chi-Square Tabel maka Ho diterima.

Jika Chi-Square Hitung >Chi-Square Tabel maka Ho ditolak. 


\section{HASIL DAN PEMBAHASAN}

\section{Hasil analisis deskriptif frekuensi}

Pengetahuan responden tentang rencana redenominasi mata uang rupiah dapat dikelompokkan menjadi dua kategori yaitu tahu dan tidak tahu. Hasil penelitian menunjukkan bahwa sebanyak 42 orang $(42 \%)$ responden tahu tentang rencana redenominasi mata uang rupiah, sedangkan sebanyak 58 orang $(58 \%)$ responden lainnya tidak tahu dengan rencana redenominasi, seperti pada table berikut :

Tabel 1. Pengetahuan responden tentang redenominasi

\begin{tabular}{lc}
\hline Pengetahuan tentang redenominasi & Frekuensi \\
\hline Tahu & 42 \\
Tidak tahu & 58 \\
\hline Total & $\mathbf{1 0 0}$ \\
\hline Sumber: Data diolah, 2019
\end{tabular}

Sumber: Data diolah, 2019

Dapat disimpulkan bahwa dari 100 orang responden yang diteliti, lebih banyak responden yang tidak tahu daripada yang tahu tentang rencana kebijakan tersebut. Hal ini mungkin disebabkan karena sosialisasi pemerintah dan Bank Indonesia belum merata kepada seluruh masyarakat Indonesia. dari hasil wawancara dengan responden juga diketahui bahwa sebagian besar responden tidak pernah mendengar tentang wacana ini walaupun sudah pernah di tayangkan di televisi, surat kabar, koran dan media lainnya. Walaupun ada sebagian responden yang tahu tentang ini, namun hanya pernah mendengar saja misalnya dari mulut ke mulut namun tidak paham apa itu redenominasi dan bagaimana penerapannya.

Persepsi atau pendapat responden terhadap rencana redenominasi mata uang rupiah dikelompokkan menjadi dua, yaitu setuju dan tidak setuju. Berdasarkan di bawah dapat dilihat bahwa dari 100 orang responden yang diteliti, hanya sebanyak 47 orang $(47 \%)$ responden yang setuju jika redenominasi dilaksanakan. Mereka setuju karena beranggapan bahwa setelah redenominasi diterapkan nilai tukar kita akan meningkat karena nilainya hampir mendekati dollar. Sedangkan sisanya sebanyak 53 orang (53\%) responden tidak setuju, karena kebijakan redenominasi hanya akan membuat nilai tukar kita semakin rendah nantinya jika pemerintah tidak dapat mengendalikan inflasi pasca redenominasi. Selain itu juga dapat membuat perekonomian tidak stabil dan membingungkan serta menyulitkan masyarakat, terutama masyarakat awam dan masyarakat yang tidak memahami redenominasi atau bagi masyarakat yang buta huruf dan yang berpendidikan rendah.

Tabel 2. Pendapat responden tentang rencana kebijakan redenominasi

\begin{tabular}{lc}
\hline \multicolumn{1}{c}{ Pengetahuan tentang redenominasi } & Frekuensi \\
\hline Tahu & 42 \\
Tidak tahu & 58 \\
\hline Total & $\mathbf{1 0 0}$ \\
\hline
\end{tabular}

Sumber: Data diolah, 2019

Jadi lebih banyak responden yang tidak setuju daripada yang setuju jika redenominasi diterapkan di Indonesia. Hal ini terjadi karena masyarakat banyak yang tidak paham dan tidak mengetahui apa itu redenominasi. Walaupun ada yang tahu atau pernah mendengar tentang istilah ini, tetapi mereka tidak mengetahui makna redenominasi sebenarnya sebelum dijelaskan oleh peneliti. Hal ini disebabkan karena kurangnya sosialisasi dari pemerintah dan Bank Indonesia kepada masyarakat.

\section{Hasil analisis deskriptif tabulasi silang (crosstabulation)}

Berdasarkan hasil distribusi antara variabel tingkat pendidikan responden dengan pengetahuan responden tentang redenominasi, maka tidak semua responden tahu 
atau paham dengan kebijakan redenominasi. Dari 100 responden, hanya sebanyak 42 orang $(42 \%)$ yang tahu tentang redenominasi, sedangkan sisanya 58 orang $(58 \%)$ tidak tahu. Jadi lebih banyak responden yang tidak tahu atau tidak paham daripada yang tahu mengenai kebijakan tersebut. Jika dilihat berbagai tingkat pendidikan yang banyak tahu atau paham tentang rencana redenominasi adalah responden dengan latar belakang pendidikan Diploma dan Sarjana. Sedangkan responden dengan latang belakang pendidikan seperti tidak punya ijazah, SD, SMP dan SMA, sebagian besar tidak tahu dan tidak paham tentang rencana kebijakan redenominasi ini.

Untuk mengetahui terdapat hubungan antara tingkat pendidikan responden dan rencana redenominasi, digunakan statistik Chi-Square Test, dimana hasilnya nilai pvalue pearson Chi-square 0,113(>0,10). Maka Ho diterima, artinya tidak terdapat hubungan antara tingkat pendidikan responden dan pengetahuan tentang redenominasi.

Tabel 3. Crosstabulation tingkat pendidikan responden dengan pengetahuan terhadap redenominasi

\begin{tabular}{|c|c|c|c|}
\hline \multirow{2}{*}{$\begin{array}{l}\text { Variabel tingkat pendidikan } \\
\text { responden }\end{array}$} & \multicolumn{2}{|c|}{$\begin{array}{c}\text { Pengetahuan tentang kebijakan } \\
\text { redenominasi }\end{array}$} & \multirow[t]{2}{*}{ Total } \\
\hline & Tahu & Tidak tahu & \\
\hline Tidak Tamat SD & 5 & 13 & 18 \\
\hline SD/MI & 6 & 17 & 23 \\
\hline SMP/MTs & 9 & 9 & 18 \\
\hline SMA/SMK/MA & 14 & 16 & 30 \\
\hline DI/DII/DIII & 3 & 1 & 4 \\
\hline DIV/S1-S3 & 5 & 2 & 7 \\
\hline Total & 42 & 58 & 100 \\
\hline
\end{tabular}

Sumber: Data diolah, 2019

Berdasarkan hasil distribusi antara variabel tingkat pendidikan responden dengan rencana kebijakan redenominasi adalah tidak semua responden setuju dengan kebijakan redenominasi. Dari 100 responden, hanya sebanyak 47 orang (47\%) yang setuju jika redenominasi dilaksanakan, sedangkan sisanya 53 orang $(53 \%)$ tidak setuju. Jadi lebih banyak responden yang tidak setuju daripada yang setuju jika redenominasi diterapkan di Indonesia. Jika dilihat dari berbagai macam tingkat pendidikan, yang banyak setuju dengan kebijakan redenominasi hanya responden yang berlatar belakang pendidikan SMP, sedangkan responden dengan latar belakang pendidikan seperti yang tidak memiliki ijazah, SD, SMA, Diploma dan Sarjana, pada umumnya tidak setuju jika redenominasi diterapkan di Indonesia. Berdasarkan Tabel 4 menunjukkan terdapat hubungan antara tingkat pendidikan responden dan rencana kebijakan redenominasi, digunakan statistik Chi-Square Test, dimana nilai p-value pearson Chi-square $0,380(>0,10)$. Maka Ho diterima, artinya tidak terdapat hubungan antara tingkat pendidikan responden dan rencana redenominasi.

Tabel 4. Cross tabulation tingkat pendidikan responden dengan rencana pemotongan nilai uang (redenominasi)

\begin{tabular}{lccc}
\hline \multirow{2}{*}{ Variabel tingkat pendidikan responden } & \multicolumn{2}{c}{ Kebijakan redenominasi } & \multirow{2}{*}{ Total } \\
\cline { 2 - 3 } & Setuju & Tidak setuju & \\
\hline Tidak Tamat SD & 8 & 10 & 18 \\
SD/MI & 10 & 13 & 23 \\
SMP/MI & 11 & 7 & 18 \\
SMA/SMK/MA & 15 & 15 & 30 \\
DI/DII/DIII & 0 & 4 & 4 \\
DIV/S1-S3 & 3 & 4 & 7 \\
\hline Total & $\mathbf{4 7}$ & $\mathbf{5 3}$ & $\mathbf{1 0 0}$ \\
\hline
\end{tabular}

Sumber: Data diolah, 2019 
Berdasarkan hasil distribusi antara variabel tingkat pendidikan responden dengan dampak redenominasi terhadap inflasi, maka tidak semua responden berpendapat bahwa redenominasi berdampak terhadap inflasi. Dari 100 responden, sebanyak 29 orang (29\%) yang menjawab ya bahwa redenominasi berdampak terhadap inflasi jika dilaksanakan di Indonesia, dan 12 orang (12\%) menjawab bahwa redenominasi tidak ada pengaruhnya terhadap inflasi. Sedangkan sisanya sebanyak 59 orang $(59 \%)$ menjawab tidak tahu. Jadi lebih banyak responden yang tidak tahu apakah redenominasi berdampak terhadap inflasi jika redenominasi diterapkan di Indonesia. Jika dari berbagai macam tingkat pendidikan, yaitu dari responden yang tidak memiliki ijazah sampai pada tingkat Sarjana secara umum menjawab tidak tahu apakah redenominasi berdampak atau tidak terhadap terjadinya inflasi di Indonesia.

Tabel 6. Crosstabulation tingkat pendidikan responden dengan dampak redenominasi terhadap inflasi

\begin{tabular}{lcccc}
\hline \multirow{2}{*}{$\begin{array}{c}\text { Variabel tingkat pendidikan } \\
\text { responden }\end{array}$} & \multicolumn{3}{c}{$\begin{array}{c}\text { Dampak redenominasi terhadap } \\
\text { inflasi }\end{array}$} & \multirow{2}{*}{ Total } \\
\cline { 2 - 4 } & Ya & Tidak & $\begin{array}{c}\text { Tidak } \\
\text { Tahu }\end{array}$ & \\
\hline Tidak Tamat SD & 4 & 1 & 13 & 18 \\
SD/MI & 5 & 2 & 16 & 23 \\
SMP/MI & 6 & 2 & 10 & 18 \\
SMA/SMK/MA & 10 & 5 & 15 & 30 \\
DI/DII/DIII & 2 & 0 & 2 & 4 \\
DIV/S1-S3 & 2 & 2 & 3 & 7 \\
\hline Total & $\mathbf{2 9}$ & $\mathbf{1 2}$ & $\mathbf{5 9}$ & $\mathbf{1 0 0}$ \\
\hline
\end{tabular}

Sumber: Data diolah, 2019

Untuk mengetahui terdapat hubungan antara tingkat pendidikan responden dan dampak redenominasi terhadap inflasi, digunakan statistik Chi-Square Test, dimana nilai p-value pearson Chi-square 0,737(>0,10). Maka Ho diterima, artinya tidak terdapat hubungan antara tingkat pendidikan responden dan dampak redenominasi terhadap inflasi.

Berdasarkan hasil distribusi antara variabel tingkat pendidikan responden dengan dampak redenominasi terhadap tabungan yaitu sebagian besar responden beranggapan tabungan mereka tetap sama setelah redenominasi atau redenominasi tidak terlalu berpengaruh terhadap tabungan. Dari 100 responden, sebanyak 30 orang (30\%) yang menjawab bahwa redenominasi dapat mengurangi tabungan, dan hanya 2 orang (2\%) yang berpendapat bahwa redenominasi Jika dilihat dari berbagai macam tingkat pendidikan, yaitu dari responden yang tidak memiliki ijazah sampai pada tingkat Sarjana secara umum mengatakan bahwa tabungan mereka tetap sama setelah redenominasi.

Tabel 7. Crosstabulation tingkat pendidikan responden dengan dampak redenominasi terhadap tabungan

\begin{tabular}{lcccc}
\hline \multirow{2}{*}{$\begin{array}{l}\text { Variabel tingkat } \\
\text { pendidikan responden }\end{array}$} & \multicolumn{2}{c}{ Dampak redenominasi terhadap tabungan } & \multirow{2}{*}{ Total } \\
\cline { 2 - 4 } & Berkurang & Bertambah & Sama Saja & \\
\hline Tidak Tamat SD & 6 & 1 & 11 & 18 \\
SD/MI & 8 & 0 & 15 & 23 \\
SMP/MI & 4 & 0 & 14 & 18 \\
SMA/SMK/MA & 9 & 1 & 20 & 30 \\
DI/DII/DIII & 2 & 0 & 2 & 4 \\
DIV/S1-S3 & 1 & 0 & 6 & 7 \\
\hline Total & $\mathbf{3 0}$ & $\mathbf{2}$ & $\mathbf{6 8}$ & $\mathbf{1 0 0}$ \\
\hline
\end{tabular}

Sumber: Data diolah, 2019 
Untuk mengetahui terdapat hubungan antara tingkat pendidikan responden dan dampak redenominasi terhadap tabungan, digunakan statistik Chi-Square Test, dimana nilai p-value pearson Chi-square 0,885(>0,10). Maka Ho diterima, artinya tidak terdapat hubungan antara tingkat pendidikan responden dan dampak redenominasi terhadap tabungan.

Berdasarkan hasil distribusi antara variabel tingkat pendidikan responden dengan dampak redenominasi terhadap pola konsumsi, maka dapat dilihat bahwa sebagian besar responden tidak merubah pola konsumsinya walaupun redenominasi telah diterapkan.

Tabel 8. Crosstabulation tingkat pendidikan responden dengan dampak redenominasi terhadap pola konsumsi

\begin{tabular}{|c|c|c|c|c|c|c|}
\hline \multirow{2}{*}{$\begin{array}{l}\text { Variabel } \\
\text { tingkat } \\
\text { pendidikan } \\
\text { responden }\end{array}$} & \multicolumn{5}{|c|}{ Dampak redenominasi terhadap pendapatan (konsumsi dan investasi) } & \multirow[b]{2}{*}{ Total } \\
\hline & $\begin{array}{c}\text { Meningkatkan } \\
\text { jumlah } \\
\text { konsumsi }\end{array}$ & $\begin{array}{c}\text { Mengurangi } \\
\text { jumlah } \\
\text { konsumsi }\end{array}$ & $\begin{array}{c}\text { Membeli } \\
\text { aset riil }\end{array}$ & $\begin{array}{l}\text { Mengkonsumsi } \\
\text { sama }\end{array}$ & Lainnya & \\
\hline Tidak Tamat SD & 0 & 6 & 0 & 11 & 1 & 18 \\
\hline $\mathrm{SD} / \mathrm{MI}$ & 0 & 8 & 0 & 15 & 0 & 23 \\
\hline SMP/MI & 1 & 3 & 0 & 14 & 0 & 18 \\
\hline SMA/SMK/MA & 3 & 7 & 0 & 20 & 0 & 30 \\
\hline DI/DII/DIII & 0 & 0 & 1 & 3 & 0 & 4 \\
\hline DIV/S1-S3 & 0 & 0 & 0 & 6 & 1 & 7 \\
\hline Total & 4 & 24 & 1 & 69 & 2 & 100 \\
\hline
\end{tabular}

Sumber: Data diolah, 2019

Dari 100 responden, sebanyak 4 orang (4\%) akan meningkatkan jumlah konsumsinya jika redenominasi diterapkan, sebanyak 24 orang (24\%) akan mengurangi jumlah konsumsinya. Sementara hanya 1 orang $(1 \%)$ yang responden yang lebih memilih untuk membeli asset riil atau berinvestasi, dan sebanyak 2 orang (2\%) menjawab pilihan lainnya seperti mengkonsumsi sesuai kebutuhan. Sedangkan sebagian besar responden yaitu sebanyak 69 orang (69\%) memilih mengkonsumsi sama seperti sebelum dan sesudah redenominasi dilaksanakan. Jika dilihat dari berbagai macam tingkat pendidikan, yaitu dari responden yang tidak memiliki ijazah sampai pada tingkat Sarjana secara umum mengatakan bahwa mereka tetap mengkonsumsi sama seperti sebelum redenominasi.

Untuk mengetahui terdapat hubungan antara tingkat pendidikan responden dan dampak redenominasi terhadap pola konsumsi, digunakan statistik Chi-Square Test, dimana nilai p-value pearson Chi-square 0,002 $(<0,10)$. Maka H1 diterima, artinya terdapat hubungan antara tingkat pendidikan responden dan dampak redenominasi terhadap pola konsumsi.

Berdasarkan hasil distribusi antara variabel tingkat pendidikan dilihat bahwa tidak semua responden berpendapat bahwa redenominasi berdampak terhadap nilai tukar. Dari 100 responden, sebanyak 43 orang (43\%) yang mengatakan bahwa redenominasi berpengaruh terhadap nilai tukar jika dilaksanakan di Indonesia, selain itu sebanyak 15 orang $(5 \%)$ responden menjawab tidak ada pengaruhnya. Sedangkan sisanya 42 orang (42\%) menjawab tidak tahu. Jika dilihat dari berbagai macam tingkat pendidikan, yaitu dari responden yang tidak memiliki ijazah sampai pada tingkat Sarjana secara umum menjawab tidak tahu apakah redenominasi berdampak atau tidak terhadap nilai tukar.

Untuk mengetahui terdapat hubungan antara tingkat pendidikan responden dan rencana redenominasi, digunakan statistik Chi-Square Test, dimana nilai p-value pearson Chi-square 0,003 $(<0,10)$. Maka H1 diterima, artinya terdapat hubungan antara tingkat pendidikan responden dan dampak redenominasi terhadap nilai tukar (kurs). 
Tabel 9. Crosstabulation tingkat pendidikan responden dengan dampak redenominasi terhadap nilai tukar (kurs)

\begin{tabular}{lcccc}
\hline \multirow{2}{*}{$\begin{array}{c}\text { Variabel tingkat pendidikan } \\
\text { responden }\end{array}$} & \multicolumn{3}{c}{$\begin{array}{c}\text { Dampak redenominasi terhadap nilai } \\
\text { Tukar (kurs) rupiah }\end{array}$} & \multirow{2}{*}{ Total } \\
\cline { 2 - 4 } & Ya & Tidak & Tidak tahu & \\
\hline Tidak Tamat SD & 4 & 2 & 12 & 18 \\
SD/MI & 6 & 4 & 13 & 23 \\
SMP/MI & 9 & 4 & 5 & 18 \\
SMA/SMK/MA & 19 & 1 & 10 & 30 \\
DI/DII/DIII & 3 & 0 & 1 & 4 \\
DIV/S1-S3 & 2 & 4 & 1 & 7 \\
\hline Total & $\mathbf{4 3}$ & $\mathbf{1 5}$ & $\mathbf{4 2}$ & $\mathbf{1 0 0}$ \\
\hline Sumbernnnnnnn
\end{tabular}

Sumber: Data diolah, 2019

\section{Analisis hasil}

Dari hasil analisis penelitian yang dilakukan melalui kuesioner dan wawancara langsung dengan responden mengenai persepsi masyarakat terhadap rencana kebijakan redenominasi mata uang rupiah sebagian besar masyarakat di Kota Payakumbuh tidak tahu dan tidak paham mengenai redenominasi. Karena masyarakat tidak paham, maka lebih banyak yang berpresepsi negatif atau tidak setuju dengan rencana kebijakan tersebut. Selanjutnya masyarakat juga menganggap bahwa redenominasi itu tidak menguntungkan hanya membingungkan dan mempersulit masyarakat.

Kemudian dari analisis deskriptif yaitu hasil analisis tabulasi silang (crosstabulation), dapat diketahui bahwa: 1). Tidak terdapat hubungan antara tingkat pendidikan dengan pengetahuan atau pemahaman responden tentang redenominasi. 2).Tidak terdapat hubungan antara tingkat pendidikan dengan pendapat atau persepsi responden tentang rencana kebijakan redenominasi. 3).Tidak terdapat hubungan antara tingkat pendidikan dengan persepsi responden tentang dampak redenominasi terhadap inflasi. 4).Terdapat hubungan antara tingkat pendidikan dengan persepsi responden tentang dampak redenominasi terhadap nilai tukar (kurs). 5).Tidak terdapat hubungan antara tingkat pendidikan dengan persepsi responden tentang dampak redenominasi terhadap tabungan. 6).Terdapat hubungan antara tingkat pendidikan dengan persepsi responden tentang dampak redenominasi terhadap pola konsumsi.

\section{KESIMPULAN DAN SARAN}

Jadi secara umum dapat disimpulkan bahwa sebagian besar masyarakat di Kota Padang tidak setuju dengan rencana kebijakan redenominasi mata uang rupiah karena mereka tidak tahu atau tidak paham tentang kebijakan tersebut. Selain itu juga diketahui bahwa redenominasi tidak memiliki dampak yang real terhadap aktifitas perekonomian, seperti inflasi, nilai tukar, tabungan dan pola konsumsi. Selanjutnya jika dilihat hubungan atau pengaruh antara variabel yang diteliti dapat diketahui bahwa tingkat pendidikan responden yang dilihat dari tingkat pendidikan rendah dan tinggi hanya sedikit pengaruhnya terhadap persepsi mereka tentang rencana kebijakan redenominasi. Dimana hanya terdapat hubungan antara tingkat pendidikan dengan persepsi responden mengenai dampak redenominasi terhadap nilai tukar dan pola konsumsi. Sementara itu tidak terdapat hubungan antara tingkat pendidikan dengan pengetahuan responden tentang redenominasi, pendapat mengenai rencana kebijakan redenominasi serta persepsi responden tentang dampak redenominasi terhadap inflasi dan tabungan. 


\section{DAFTAR PUSTAKA}

Agyeman, Francis K. A., dan Emmanual Kofi M. (2014). The benefits and challenges of ghana's redenomination exercise to market women - A Case study of adum, kejetia, and central markets in kumasi metropolis. Researcjournali's Journal of Accounting, 2(1), 1-27

Alhusain, Achmad Sani. (2012). Rencana redenominasi rupiah. Info Singkat Ekonomi dan Kebijakan Publik, Vol. IV, No. 24/II/P3DI

Amir, Amri. (2011). Redenominasi rupiah dan sistem keuangan. Jurnal Paradigma Ekonomika.1(4), 73-86

Arikunto S. (2006). Prosedur penelitian suatu pendekatan praktik, Ed Revisi VI. PT Rineka Cipta: Jakarta

Astrini, Danti. (2014). Kajian dampak redenominasi terhadap perekonomian dengan metode percobaan ekonomi. Tesis. Sekolah Pascasarjana, Institut Pertanian Bogor

Atmadja, A. S. (1999). Inflasi di Indonesia: sumber-sumber penyebab dan pengendaliannya. Jurnal Akuntansi dan Keuangan, 1(1), 55-67

Aziz R. (2007). The redenomination of the ghananian currency, the Cedi. School of Management Blekinge Institute of Technology, 1-85.

Bayir, Ilker, (2012). Currency reform in turkey and lessons from re-denomination and euro changeover, Journal of Money and Economy, 6(2), 1-33,

Bernholz, Peter. (1995). Hyperinflasion and currency in bolivia: studied from a general perfective. PP. 227-254 in Pierre L. Siklos, ed., Great Inflations of the 20 th Century, Theories, Policies and Evidence. Aldershot, UK: Edward Elgar

Badan Pusat Statistik. (2011). Padang dalam angka 2011-2018. BPS Provinsi Sumatera Barat

Hardiyanto, Arif dan Murni Daulay. (2013). Analisis persepsi masyarakat di kota medan terhadap rencana redenominasi. Jurnal Ekonomi dan Keuangan, 1(4).

Ioana, D. (2012). The national currency redenomination experience in several countries: a comparative analysis.Working Paper.Titu Maiorescu University Bucharest

Kesumajaya, I.W.W. (2011). Redenominasi mata uang rupiah merupakan bagian dari tugas bank Indonesia untuk mengatur dan menjaga kelancaran sistim pembayaran di indonesia. GaneC Swara, 5 (1), 1-6

Mosley, L. (2005). Dropping zeros, gaining credibility? currency redenomination in developing nations.Working Paper. Dept. of Political Science University of North Carolina, 1-28

Pambudi A., Bambang J., dan D.S. Priyarsono. (2014). Penentu keberhasilan redenominasi mata uang: pendekatan historisdan eksperimental. Buletin Ekonomi Moneter dan Perbankan, 17(2).

Priyono. (2013). Redenomination; between hope and reality (the study of the implementation of the redenomination in Indonesia). International Journal of Bussiness and Management Invention. April 2013. 2(4),36-40

Sugiyono. (2009). Metode penelitian kuantitatif dan kualitatif. CV.Alfabeta: Bandung

Suhendra, E.S., dan S.W. Handayani. (2012). Impacts of redenomination on economics indicator. International Conference on Eurasian Economics, 18-22

Umar. (2000). Metodologi Penelitian untuk Bisnis. Salemba Empat: Jakarta

Wijaya, Adityadharma. (2014). Pengujian abnormal return pada peristiwa redenominasi mata uang di Turki. Calypta: Jurnal Ilmiah Mahasiswa Universitas Surabaya, $3(1), 1-24$ 